\title{
How Effective Were the Beach Nourishments at Cancun?
}

\author{
Raúl Martell ${ }^{1}$, Edgar Mendoza ${ }^{2, *}$ E , Ismael Mariño-Tapia ${ }^{3}$, Itxaso Odériz ${ }^{2}$ and \\ Rodolfo Silva ${ }^{2}$ (D) \\ 1 Comisión Nacional para el Conocimiento y uso de la Biodiversidad, CONABIO, Mexico City 14010, Mexico; \\ rmartell@conabio.gob.mx \\ 2 Instituto de Ingeniería, Universidad Nacional Autónoma de México, Mexico City 04510, Mexico; \\ itxaso.oderiz@gmail.com (I.O.); rsilvac@iingen.unam.mx (R.S.) \\ 3 Escuela Nacional de Estudios Superiores Unidad Mérida, Universidad Nacional Autónoma de México, \\ Mérida, Yucatán 97357, Mexico; imarino@enesmerida.unam.mx \\ * Correspondence: emendozab@iingen.unam.mx; Tel.: +52-55-5623-3600
}

Received: 4 May 2020; Accepted: 26 May 2020; Published: 28 May 2020

\begin{abstract}
Beach nourishment is generally seen as the preferred means of rectifying coastal erosion, due to its low environmental impact and natural evolution. The largest beach nourishment project ever carried out in Mexico took place on Cancun beach in 2006, as a response to the most intense hurricane season ever registered in Mexico, in 2005. After Hurricane Dean, in 2009, a second nourishment was conducted, which evidenced flaws in the design and execution of the first project. Previous investigations report that the need for beach re-fills directly correlates with wave energy. However, following a thorough revision of the extreme climatic events that occurred between 1978 and 2018, it has been found that the amount of erosion also depends on the frequency and duration of high energy events. The findings also show that the apparent success of the second nourishment is mainly associated with a decline in the number of extreme wave power events impacting the beach. In the conclusion to this paper, we share the knowledge gained, but not yet applied, in Mexico or elsewhere, regarding beach use, urbanization, and protection in beach planning.
\end{abstract}

Keywords: beach nourishment; Cancun beach; coastal erosion; hurricane damage; beach nourishment assessment; beach profile imbalance

\section{Introduction}

It has long been recognized that sandy beaches around the world are being eroded, e.g., [1,2] estimated that $70 \%$ of beaches were undergoing erosion and, according to [3], the problem was much more critical in the USA, where the figure was $90 \%$. In the Caribbean Basin, $[1,4,5]$ have estimated severe erosion rates for various beaches. In areas where there is potential for tourist or urban development, and erosion problems are detected, scientifically based engineering solutions are expected to control or mitigate these phenomena, e.g., [6].

Over time, the methodologies used for these solutions have evolved, e.g., [7]. In the past, the most frequently applied techniques were based on hardening the coast, by means of dikes, breakwaters, groins, etc. Despite initial criticism, the use of softer solutions (i.e., artificial beach nourishment) has gained popularity, becoming the preferred alternative for mitigating erosion [8-10]. The documented benefits [11-13] of artificial nourishment include:

- The extension of the berm and beach profile, combined with protective dunes, dissipates wave energy, thus reducing expected damage from storms. 
- The berm is aesthetically valuable for tourism.

- The extension of the beach increases its lifespan by delaying long-term chronic erosion.

- The profile gradually re-shapes to fit the hydrodynamic conditions of the area, promoting stable conditions.

- If the correct source of sediment is chosen (sorting, shape, quality and density), the nourishment will not induce drastic changes to the water current circulation patterns: color, transparency, temperature, pH, Dissolved Oxygen, Biological Oxygen Demand, Biochemical Oxygen Demand. Nor will it impact organisms, such as nekton, plankton and benthos.

- Structural erosion (scouring) is avoided.

- Implementation and maintenance costs are lower than those corresponding to rigid engineering works.

These benefits mean that when a beach has a sand deficiency, is important in terms of economic impact and job creation, and the environmental impacts are not very serious, beach nourishment can be seen as a feasible alternative to remedy problems of erosion.

In 1923, over a million cubic meters of sand were placed on a beach near Coney Island, New York, making this the first cited case of artificial beach nourishment in modern times [13,14]. From then until the 1950s some 72 beaches in the USA were artificially nourished. However, not all of these projects were based on scientific grounds, and most were carried out empirically. Many of the projects had a short life, arguably due to the inappropriate selection of the sediment used. In the United States and Europe, from the 1950s to the 1970s, many authors, including [15-19], offered technical criteria for the design of beach nourishment projects. These works formed the scientific basis for various compilations, such as [8,20-23], from which most artificial sand nourishment projects worldwide have taken their evidence.

In Europe, the Netherlands leads the field in coastal protection, with $50 \%$ of its territory being below sea level. In 1984 the Netherlands introduced regulations for coastal protection based on artificial nourishment of their beaches and sand dunes [24]. The research carried out there and the experience accumulated confirmed the functional efficiency of this technique, as well as its adaptability and lower costs, compared to alternative methods [25]. Researchers in the Netherlands have contributed considerably to the knowledge of the criteria for designing sand nourishment projects, including the dune, berm, and submerged beach. Between 1952 and 1989, 60 million cubic meters of sand were placed on the coast of the Netherlands in over 50 projects. From the experience gained, in 1990 the Dutch government stated that beach nourishment was the first option in adapting to climate change, and an innovative large-scale beach nourishment project was begun, using the so-called Sand Engine strategy [26].

Important artificial nourishment projects have also been executed in Spain, Germany, the United Kingdom, France, Portugal, Georgia, Japan, and Australia. In the Caribbean area, some projects in Mexico, Cuba, and the Dominican Republic stand out, because of the large amount of biogenic sand required in the nourishments.

As with any engineering work, beach nourishment projects have a limited lifetime. This lifespan depends upon the sediment transport induced by the power and persistence of extreme sea states and the resilience of the system [27]. According to [28], an artificially nourished beach will have to be re-nourished, depending on the characteristics of its design and evolution. Artificial sand nourishment is simply a mitigation procedure, which needs periodic maintenance. If the environmental conditions are favorable, infilling intervals can be extended, with corresponding financial savings. On the other hand, it is accepted that if the intensity and frequency of the storms in the area increase, the erosion rates will also rise, as will associated costs of sand refills, perhaps making the whole procedure unsustainable. However, together with the intensity, the duration of heavy sea states is a variable which determines the lifespan of a beach nourishment. In any case, alternative measures should always be considered, 
including the use of rigid structures. If that also fails, a managed retreat of the infrastructure would be the only alternative.

Assessing the effectiveness of sand nourishment projects is important from both economic and technical perspectives. This is done through a monitoring program, by periodically measuring the morphological changes of the beach. The aim of this work is to assess the effectiveness of two beach nourishments carried out at Cancun, Mexico, in 2006 and 2009, using a total of 8 million cubic meters of sand. This assessment uses satellite images, photographs, and model-derived wave power records to examine the morphological evolution of the coastline over the last 40 years.

\section{Cancun Before the First Beach Nourishment}

Cancun is located on the Caribbean coast of the Yucatan Peninsula, in Mexico (Figure 1). The beach is a prime example of an environment which has been progressively degraded by human activities linked to tourism. The urbanization of Cancun started in the late 1960s on a pristine barrier island between the Caribbean Sea and a system of coastal lagoons (Nichupté). The lagoons are supplied with fresh water, via continental ground water discharge, and with sea water, which arrives with the tides (micro-tidal regime), through two inlets. The lagoons used to be surrounded by a very rich mangrove forest, which is now greatly reduced. The beach of Cancun lacks the protection of coral reefs and the sediment is composed mostly of biogenic sediments.

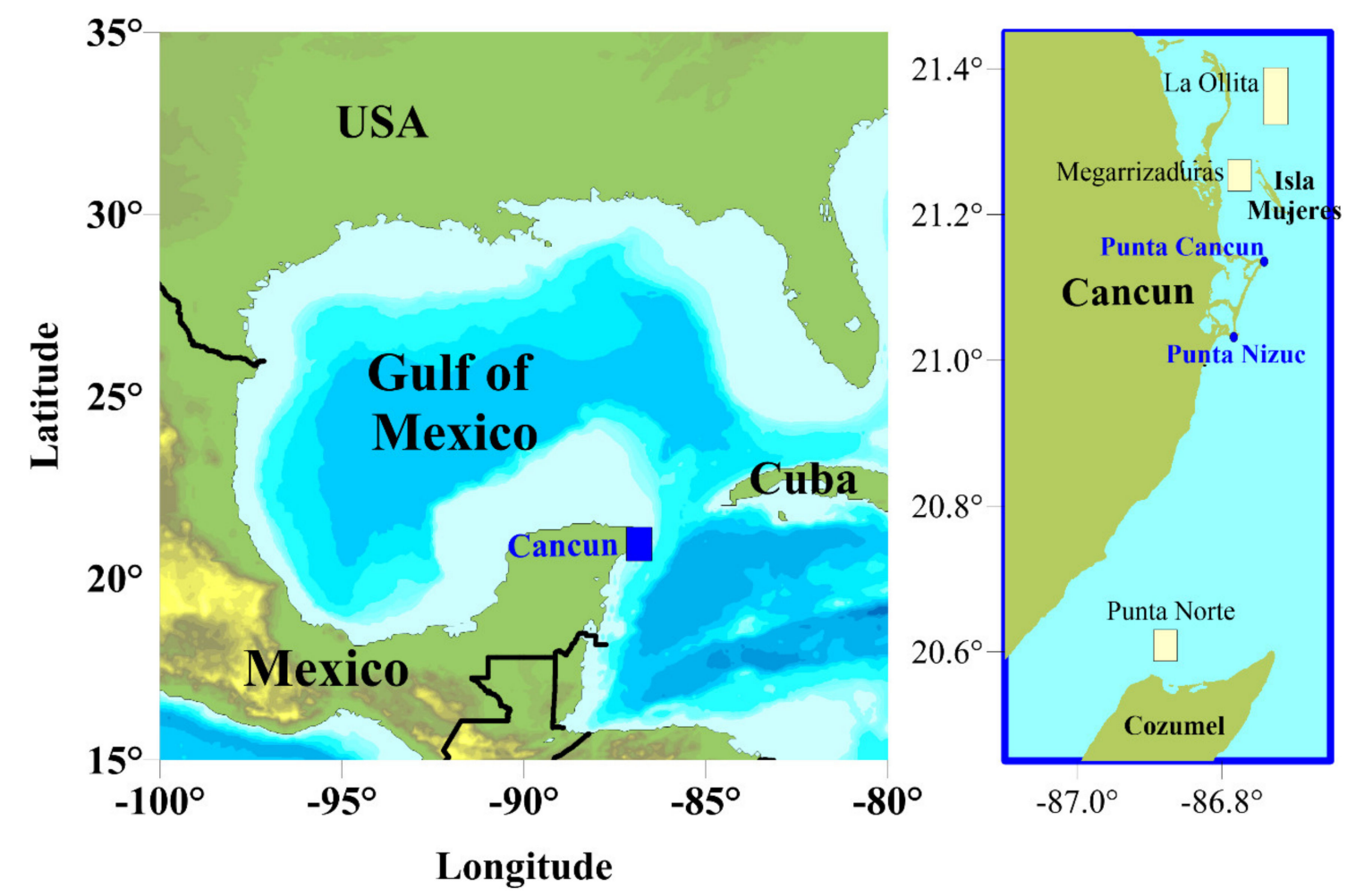

Figure 1. Location of the barrier island beach of Cancun, between Punta Cancun and Punta Nizuc.

The main anthropic alteration to the Cancun coast has been the construction of very dense infrastructure (hotels, roads, gardens, golf courses, etc.) on the dunes. The inlets were also rigidized, causing modifications to the natural breaching of the sandbar during storms, and thus limiting the interaction between the sea and lagoon. These changes, together with a decline in the amount of natural sediment availability, brought about intense erosion. Beach loss was estimated at an annual rate of $1.8 \mathrm{~m}$ for 1967-2005 [29]. Figure 2 shows Cancun in 1947, and the slow, but continuous urbanization of the beach between 1978 and 1988 . 


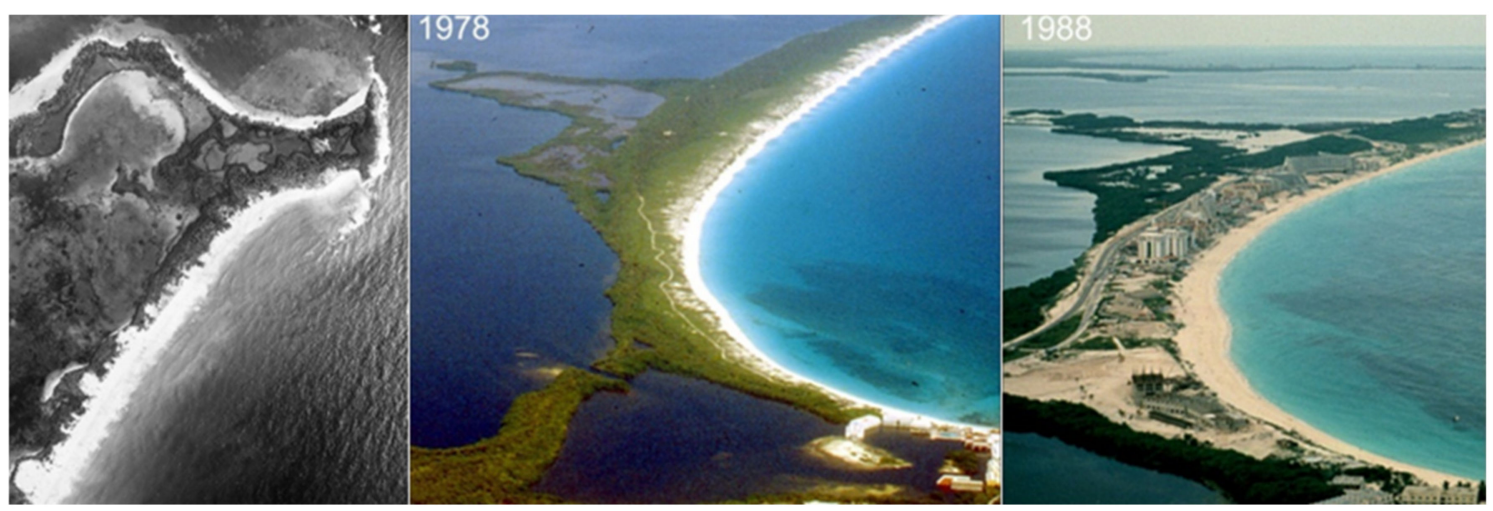

Figure 2. Historical aerial images of Cancun. Punta Cancún in 1947 (left panel) and Punta Nizuc in 1978 and 1988 (center and right panels, respectively).

As documented by [30] and [31], until 1988 the urban planning of Cancun did not take into consideration the natural dynamics of the coast. In September 1988, Cancun received the full force of hurricane Gilbert. The waves and storm surge moved massive quantities of sand and, for the first time, the hoteliers there experienced the effects of substantial erosion on the beach. Several studies were carried out, but no action was taken to recover the beach. The individual hotel owners implemented uncoordinated, inadequate coastal protection schemes (e.g., vertical walls, detached breakwaters, and groins), accelerating the problem and transferring the effects to neighboring beach segments (see Figure 3). Even so, the beach partially recovered until hurricanes Ivan (2004) and Emily (2005) hit the coast [32]. Then, in October 2005, Hurricane Wilma hit Cancun, removing 8 million $\mathrm{m}^{3}$ of sand [33]; almost all of the beach was left without sediment (Figure 4).
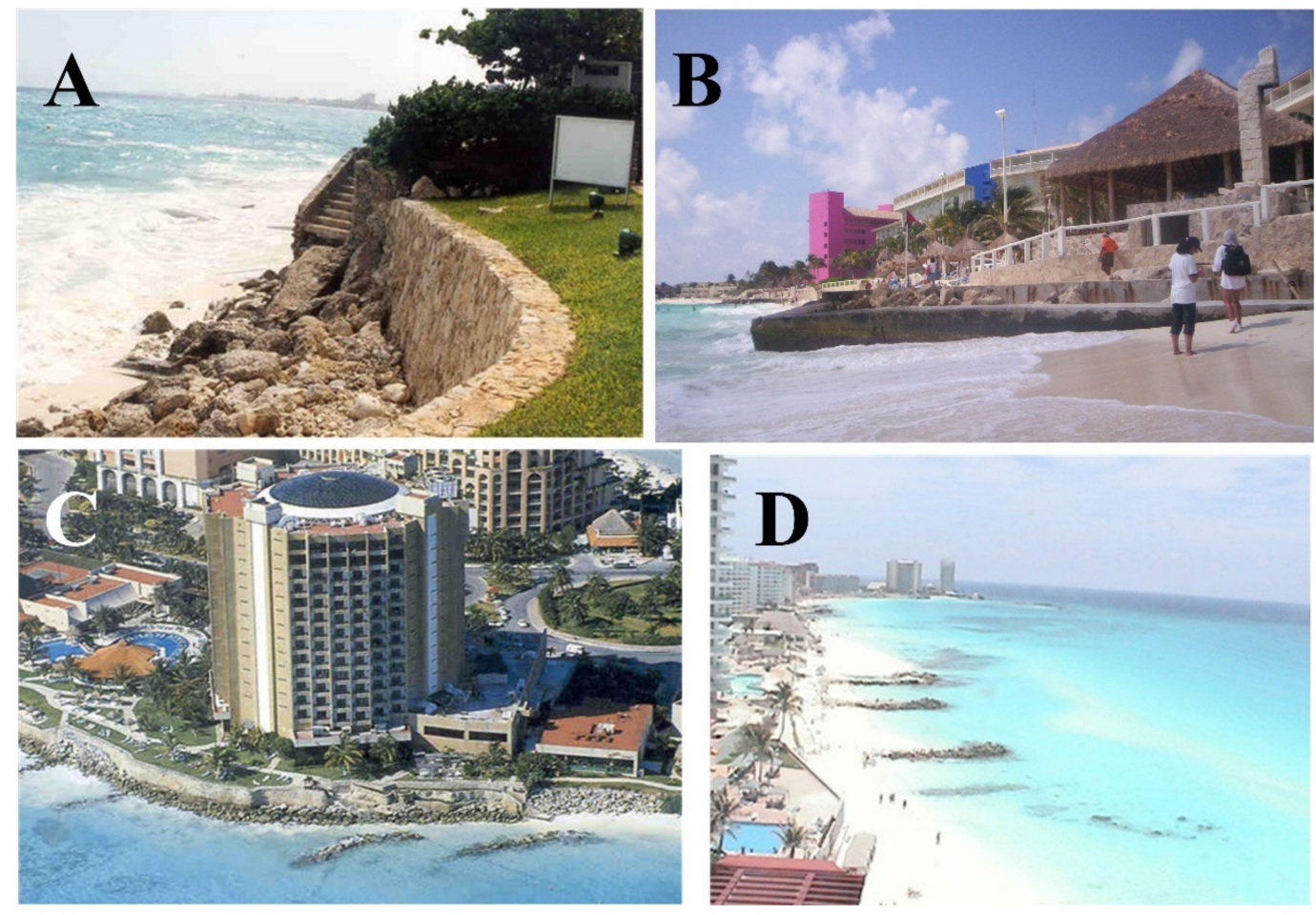

Figure 3. Examples of inadequate solutions implemented 1988-2004. Vertical walls (panels A and B); detached structures (panel C) and groins (panel D). 


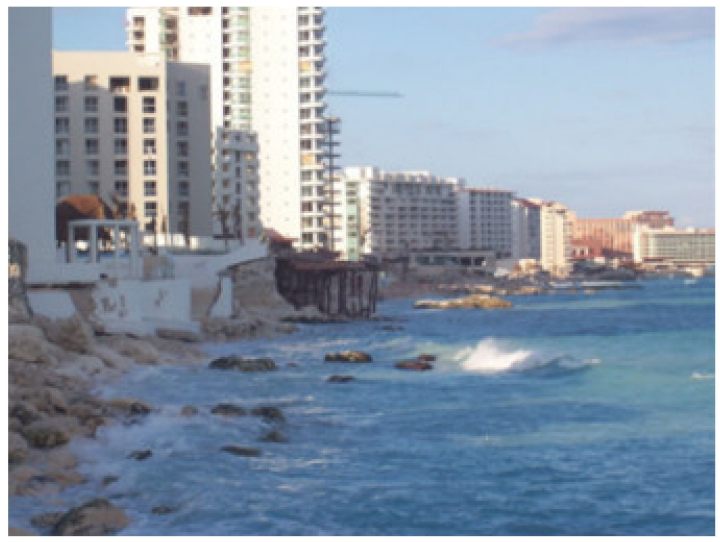

(a)

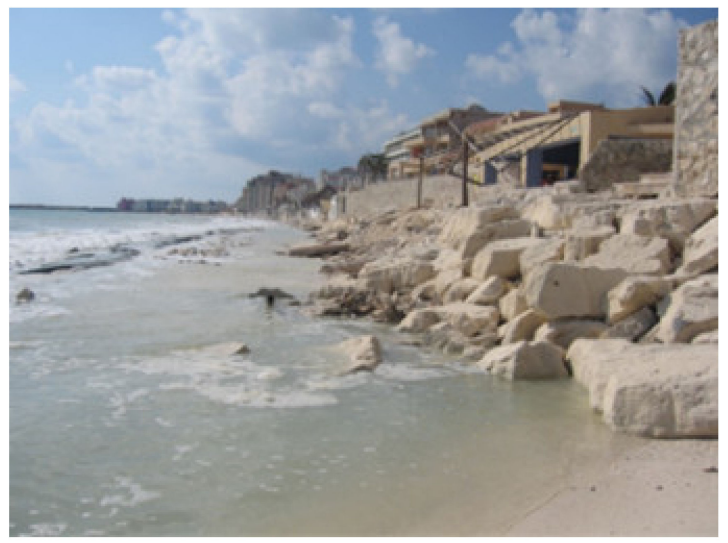

(c)

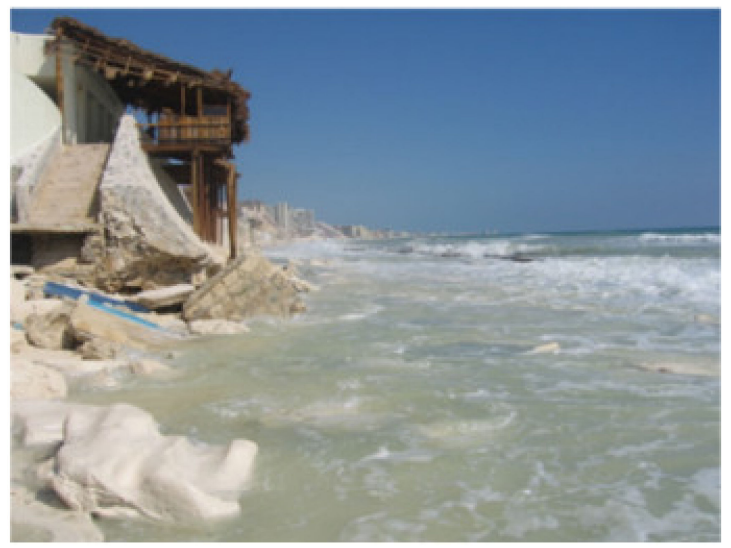

(e)

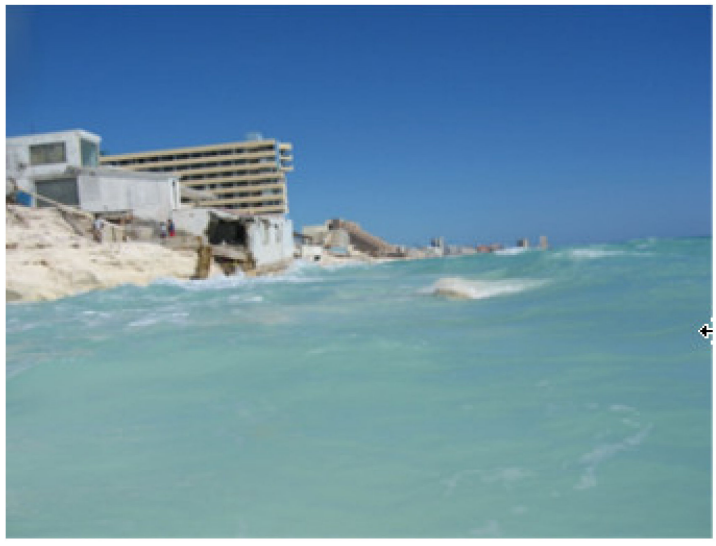

(b)

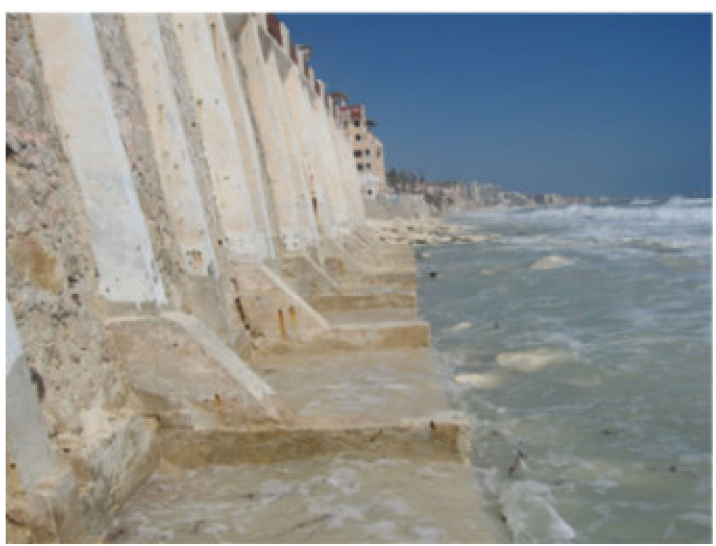

(d)

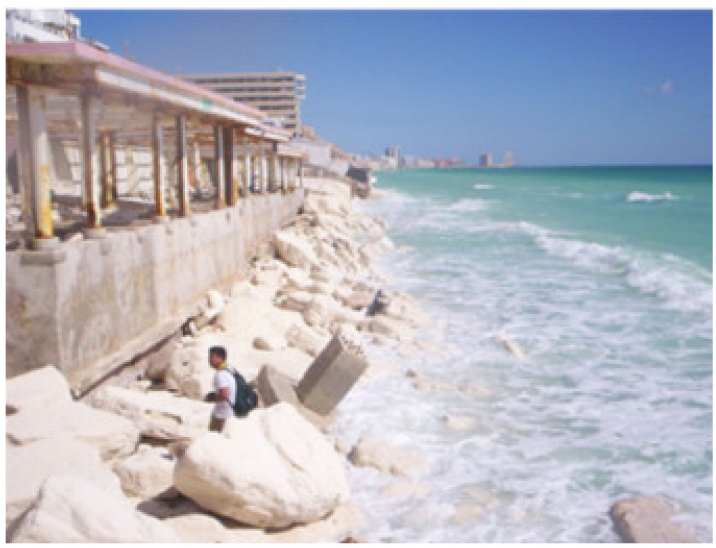

(f)

Figure 4. Examples of damage caused by Hurricane Wilma to the beach of Cancun in 2005. It can be seen that in front of many hotels the beach totally disappeared; only rocks were left behind (panels (a), (c) and (f)), while in other places, waves were hitting the hotels walls and facilities directly (panels (b), (d) and (e)).

\section{The First Beach Nourishment, 2006 to 2009}

In 2006, the problems of erosion had come to a head; the situation was critical economically as the all-important tourist industry in Cancun was in jeopardy. An urgent solution that could restore the beach immediately and activate the economy was necessary and a beach nourishment was undertaken 
to achieve this goal. From January to April 2006, 2.7 million cubic meters of sand were placed on the beach, with a cost of USD 19 million. The sediment was borrowed from two nearby sand banks of La Ollita and Megarrizaduras (Figure 1). La Ollita sand bank is $12 \mathrm{~km}$ north-east of Cancun, off the northern end of Isla Mujeres. Around 1.7 million cubic meters of sand were extracted from here, from an average depth of $25 \mathrm{~m}$ [33]. The Megarrizaduras sand bank is $15 \mathrm{~km}$ north of Punta Cancun, in shallow waters (7-10 $\mathrm{m}$ depth) between Cancun and Isla Mujeres. Around one million cubic meters of sand were extracted from this bank.

Immediately after the sand nourishment, the beach had an average width of $60 \mathrm{~m}$ (Figure 5). However, the beach rapidly began to narrow, losing an average $8 \mathrm{~m}$ in width, from May to September 2006, and even more, 29 m, from September 2006 to September 2007 [34]. In the same period, the sand on the beach formed a dramatic, pronounced scarp, making it very difficult for tourists to enjoy the beach (see upper panels of Figure 6). These scarps remained, due to the lack of sediment in the submerged part of the beach profile. The beach was dramatically damaged by hurricane Dean in August 2007.
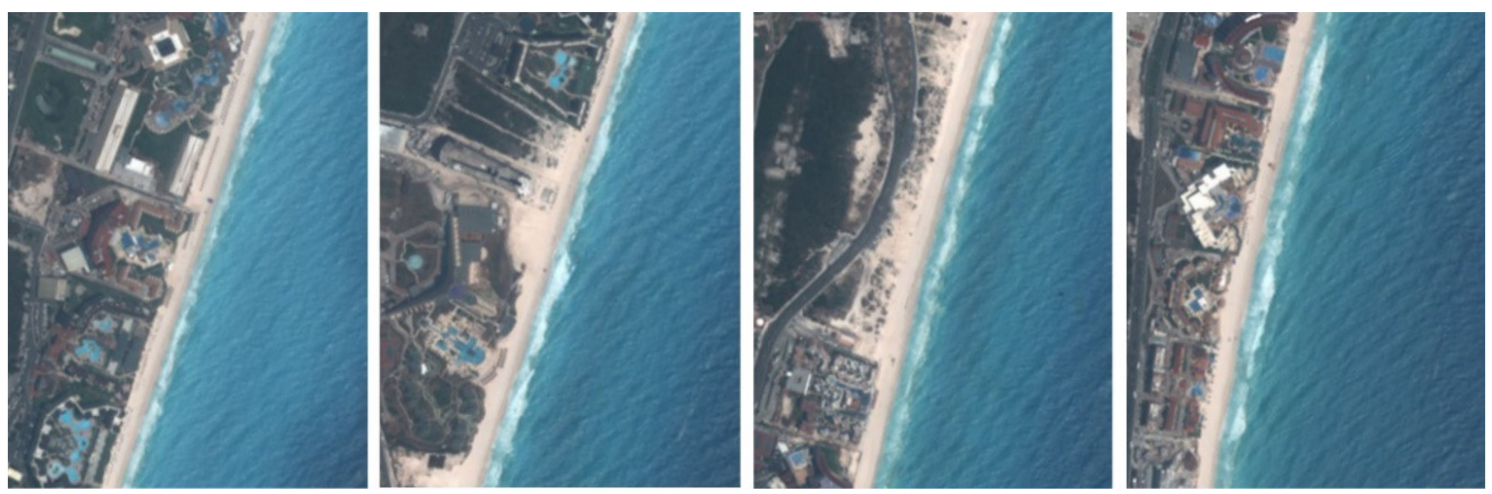

Figure 5. Aerial views (from north to south) of various segments of the central part of Cancun beach in May 2006; the immediate result obtained from the nourishment is evident.
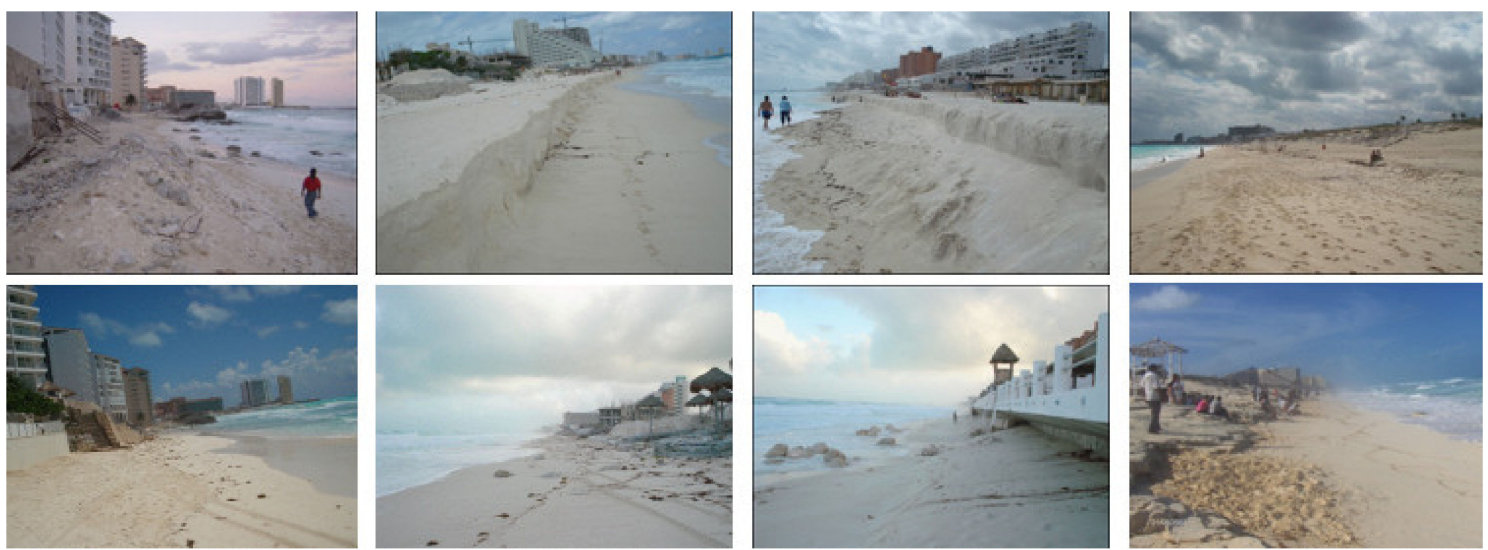

Figure 6. Examples of damage caused by Hurricane Dean to the beach of Cancun. Upper panels: August 15, 2007 (a few days before Hurricane Dean hit land), and lower panels: August 25, 2007 (a few days after Hurricane Dean had landed). Each photograph corresponds to approximately the same place in the upper and lower panel.

By 2007 the level of anthropization of the barrier island was over 95\%, with commercial centers, hotels, houses, gardens, and a wide boulevard covering almost all the areas that had originally been dunes, coastal vegetation, and mangrove (Figure 7 [35]). 


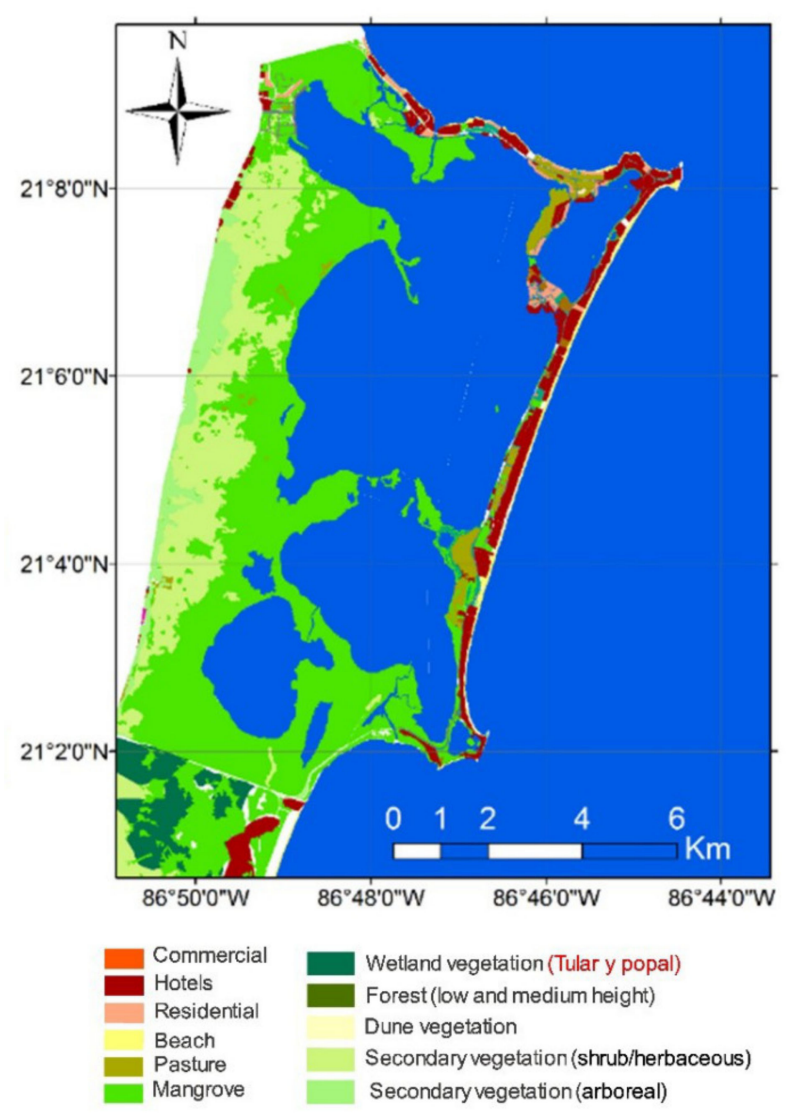

Figure 7. Land use, Cancun 2007 [35]. Intense urbanization all along the barrier rigidized the coast and facilitated the loss of beach sediment.

On 21 August 2007, Hurricane Dean hit Cancun, generating very intense waves that removed significant volumes of sand; the dry beach was reduced in width and the scarps disappeared (Figure 4). After Hurricane Dean, the erosion on the beach continued, with a recorded loss of $10 \mathrm{~m}$ of dry beach, from September 2007 to August 2008, and a further $1 \mathrm{~m}$ between August 2008 and January 2009 [36]. Although the rate of the erosion diminished, by January 2009 the waves were lapping only $14.5 \mathrm{~m}$ from the sea walls of the hotels [37]. The erosion continued, bringing a shoreline recession in the central and northern sections of the beach to a position similar to the post-Wilma conditions of 2005.

From exhaustive monitoring of the beach evolution in 2006-2009, [38] concluded that during extreme wave conditions, longitudinal currents are highly dynamic and determine sand availability at the northern and southern ends of Cancun beach. In the central part of the system, offshore sediment transport is dominant and the sediment balance is negative. This sediment imbalance prevents the natural self-regulation of the coastal system; causes very low sediment input into the system; and leads to large amounts of sediment being transported out of the system by hurricane-induced high wave energy. These conclusions have been very important in understanding the beach behavior at Cancun.

\section{The Beach Nourishment of 2010, until 2020}

Given that the beach had not reached a dynamic equilibrium, it continued eroding and consequently was not attractive for tourists (Figure 8). A second beach nourishment was therefore performed, from December 2009 to January 2010. The methodology was similar to that of 2006. However, this time the amount of sand used to replenish the beach was almost twice that of 2006 (5.2 million cubic meters). The width of the beach at the end of the process was $80 \mathrm{~m}$ and the thickness of the sand layer in the beach profile was substantially higher than that of 2006 (Figure 9). Additionally, a $305 \mathrm{~m}$ 
long breakwater crowned $2.5 \mathrm{~m}$ above the mean sea level was built on Punta Cancun, to prevent the transport of the sediment to the north.

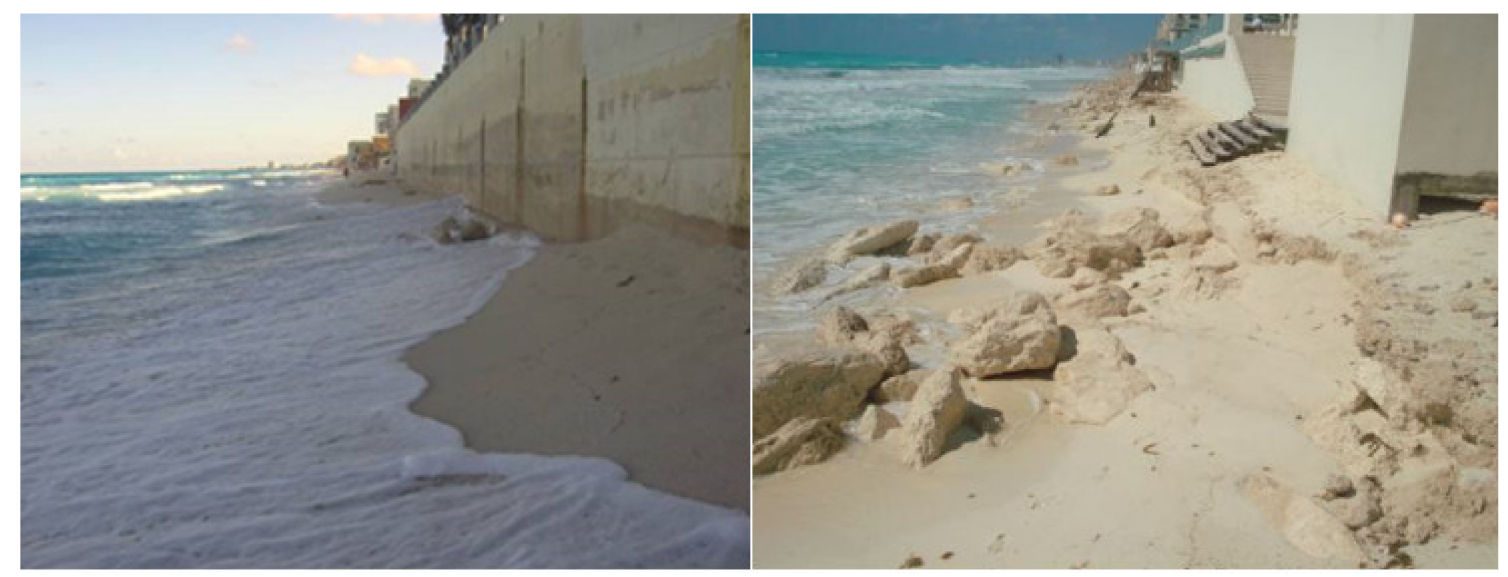

Figure 8. View of the beach at Cancun in 2009, before the second nourishment. Waves attacking the hotel facings (left) and rocks left behind after erosion (right).

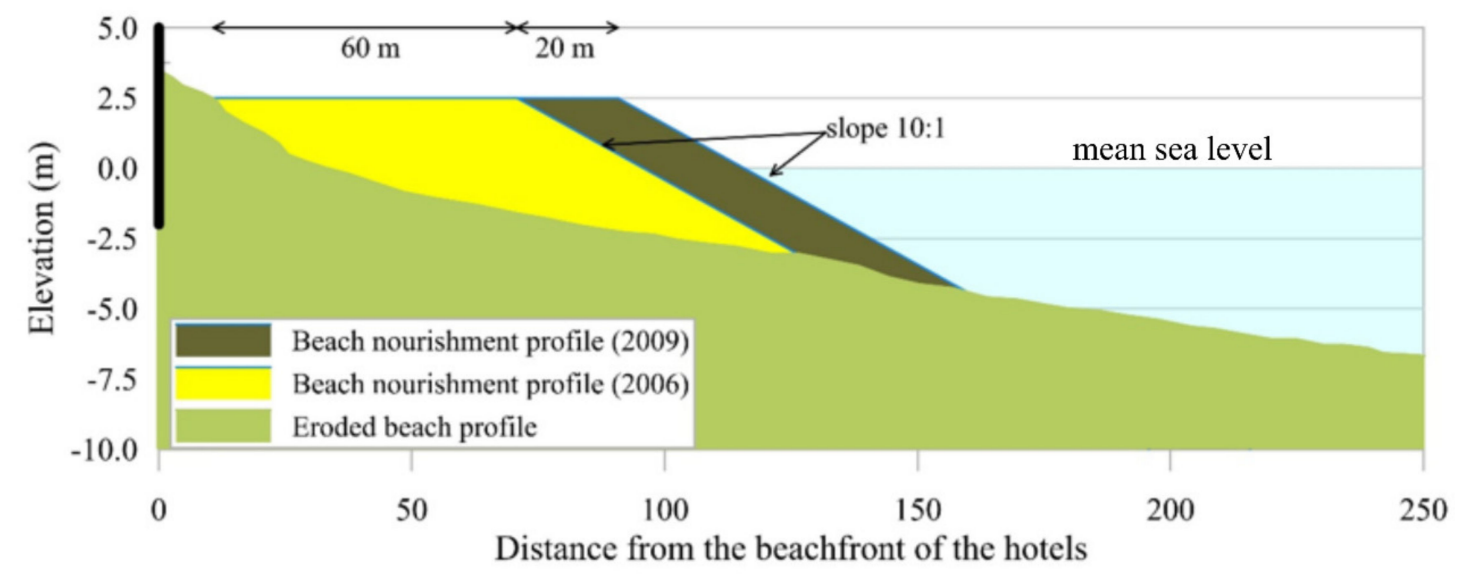

Figure 9. Projected profiles for the 2006 and 2009 beach nourishments.

For the second nourishment project, 2.5 million cubic meters of sand were extracted from La Ollita II sand bank, next to the sand bank used in 2006. The sand was extracted from an average depth of $25 \mathrm{~m}$. The remaining 2.8 million cubic meters of sediment were taken from the sandbank at Punta Norte, in the shallow waters north of the island of Cozumel, $48 \mathrm{~km}$ away, at a depth of 12-29 $\mathrm{m}$ [33]. While all the borrowed sand was of marine biogenic origin, the sand used had different mechanical characteristics from the sand native to Cancun beach (see Figure 10). The differences in the sand characteristics may explain the unpredictable behavior of sand transport on the beach and therefore the beach evolution after the second nourishment. 

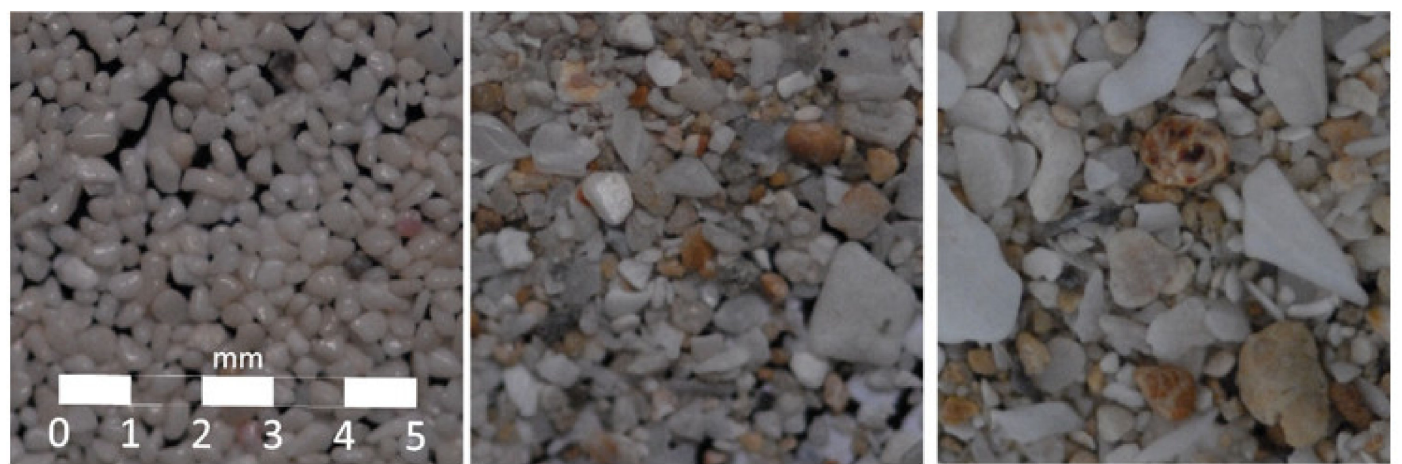

Figure 10. Left panel shows the native sand, 2004. Central and right panels, sand from the emerged and submerged beach fill, respectively.

The estimated lifespan of the second nourishment was 3 years [33], a period calculated on the basis of the trends in severe storm impacts previously observed. Nevertheless, after the beach nourishment process, the system never attained the expected profile (see Figure 11). The wave action caused a steep beach scarp to form; an unpleasant $2 \mathrm{~m}$ vertical step (Figure 12). A very thorough analysis of this process on the beach in Cancun was made by [38].
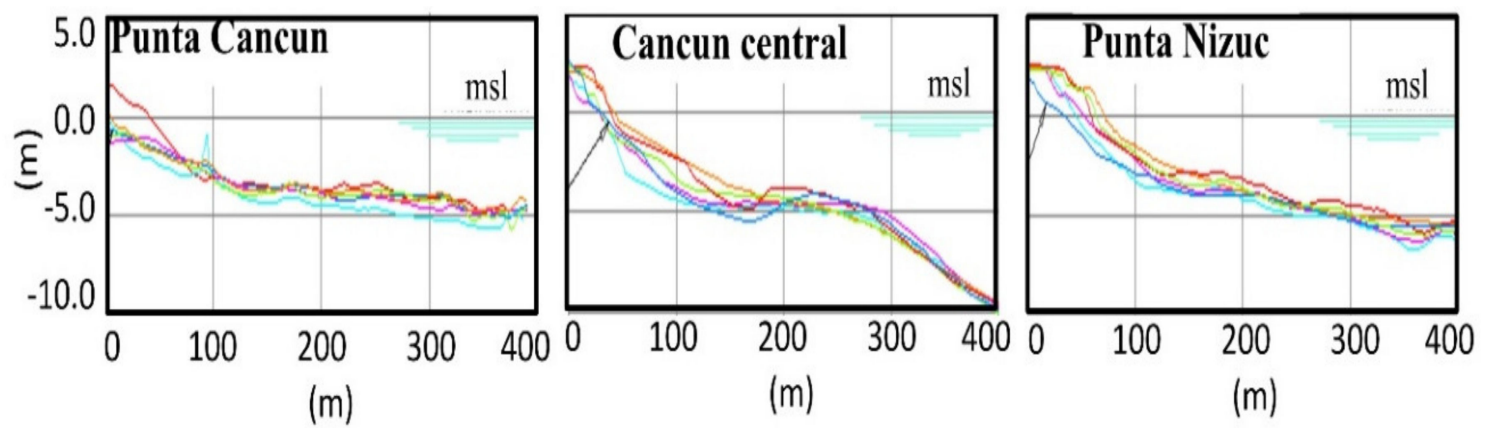

Figure 11. Beach profiles at northern (P. Cancun); central, and southern (P. Nizuc) Cancun, showing the beach growth due to the first beach fill (early 2006), and a return to erosion conditions by 2008, when the need for a 2nd nourishment was evident: Nov-2005 (--), May-2006 (--), Aug-2006 (--), Apr-2007 (--), Sep-2007 (--) and Aug-2008 (--). 


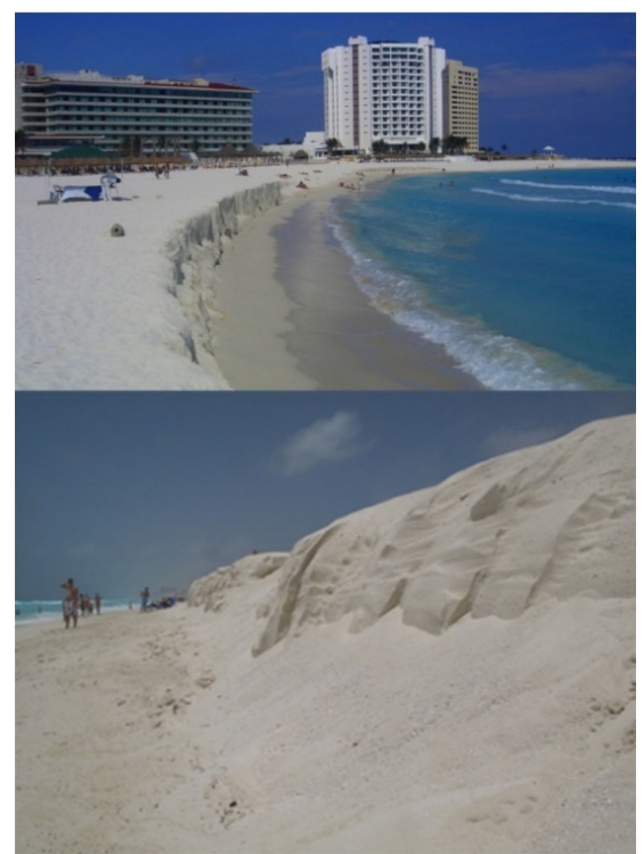

Figure 12. The second beach nourishment was carried out in June 2010. By October 2010 the beach had developed a scarp of almost $2 \mathrm{~m}$ height as seen in both photographs.

In 2013 all the scarps had disappeared (Figure 13) and, 10 years after the second nourishment, the beach at Cancun has managed to conserve a nearly stable width of approximately $30 \mathrm{~m}$ (Figures 14 and 15). Therefore, no further beach nourishments have been required.
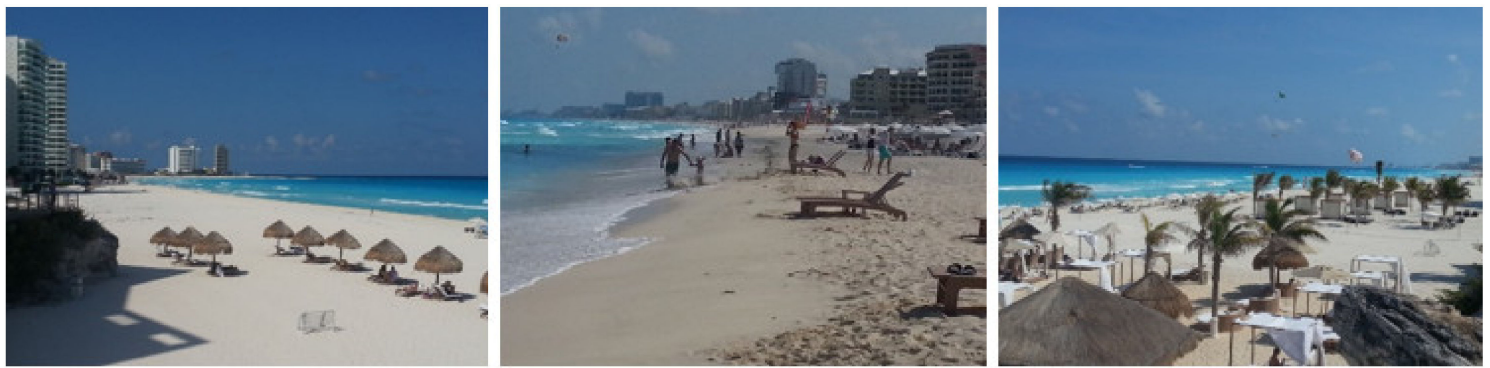

Figure 13. Aspect of the beach of Cancun in 2013. All the scarps have disappeared and the beach seems to be in a sound state. 

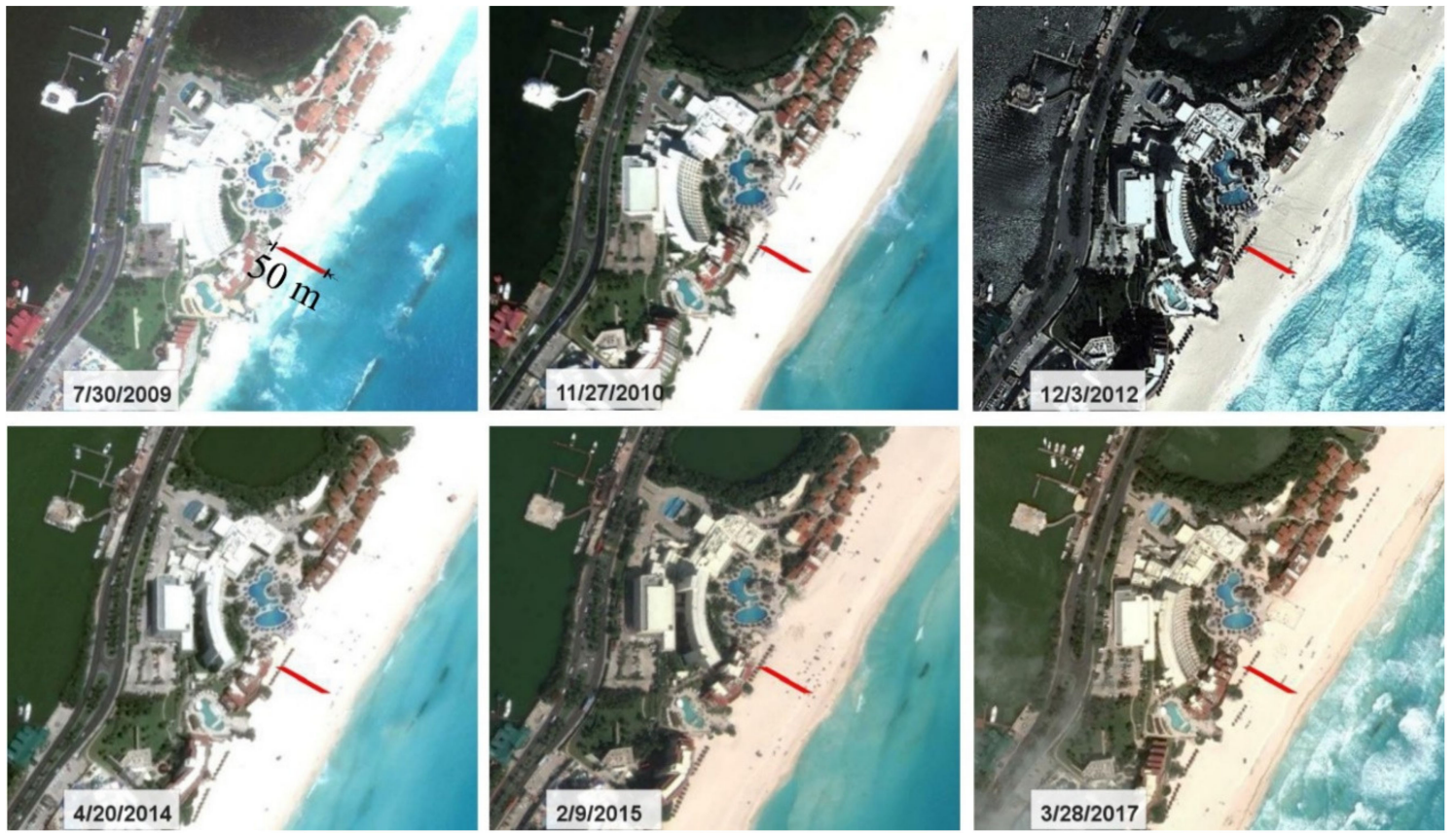

Figure 14. Satellite images, 2009 to 2017, of the beach in front of the Grand Park Royal Cancun, located in the central-north part of the beach (source: Google Earth Pro, version: 7.3.2.5776). The red line, $50 \mathrm{~m}$ long, shows the dynamic stability being reached.
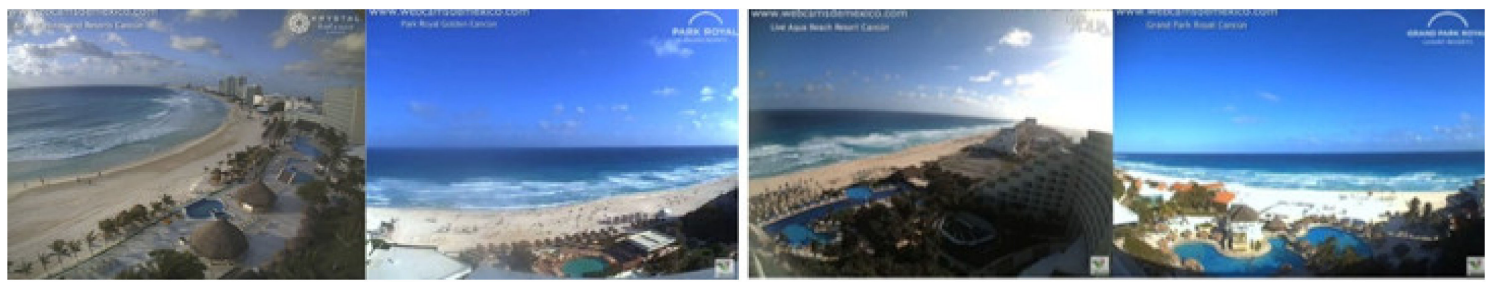

Figure 15. Recent views of the beach at Cancun, January 16, 2020 [39].

\section{Characterization of Extreme Events 1979-2018}

To evaluate the response of the beach nourishment to the wave climate, three periods, namely Stage 0 from 1979 to 2005; Stage 1 from 2006 to 2009; and Stage 2 from 2009 to 2018, were analyzed separately. For this characterization, wave records for $21.0^{\circ} \mathrm{N}$ and $86.5^{\circ} \mathrm{W}$ were used. Hourly information of significant wave height $\left(H_{s}\right)$, peak wave period $\left(T_{p}\right)$, mean wave period $\left(T_{m}\right)$, and wave direction $(\theta)$ were taken from the reanalysis dataset ERA 5 [40] of the European Centre for Medium-Range Weather Forecasts (ECMWF).

An extreme event was defined as when the significant wave height exceeds the general 90th percentile significant wave height $\left(H_{s 90}\right)$ [41]. This value was $2.10 \mathrm{~m}$ for Stages 0 and 1 , and 2.03 for Stage 2. If the difference in time between the events is more than $12 \mathrm{~h}$, these are considered independent events [42]. The deep-water parameters for each extreme event found of the wave time series were plotted against the number of events, that is: event duration, storm cluster time intervals (IN), significant wave height $\left(H_{s}\right)$, maximum significant wave height $\left(H_{s m a x}\right)$, peak period $\left(T_{p}\right)$, maximum peak period $\left(T_{p \max }\right)$ and mean wave power by event $\left(P_{w E}\right)$. The storm cluster $I N$ is the time elapsed (days) between storms [43].

The results shown in Figure 16 give an overview of the intensity, persistence, and clustering of the extreme events which occurred in each of the three stages. All of these factors are important in the morphodynamic response of the beach. In Figure 16 the variables are presented in histograms, to facilitate comparisons between the stages. 

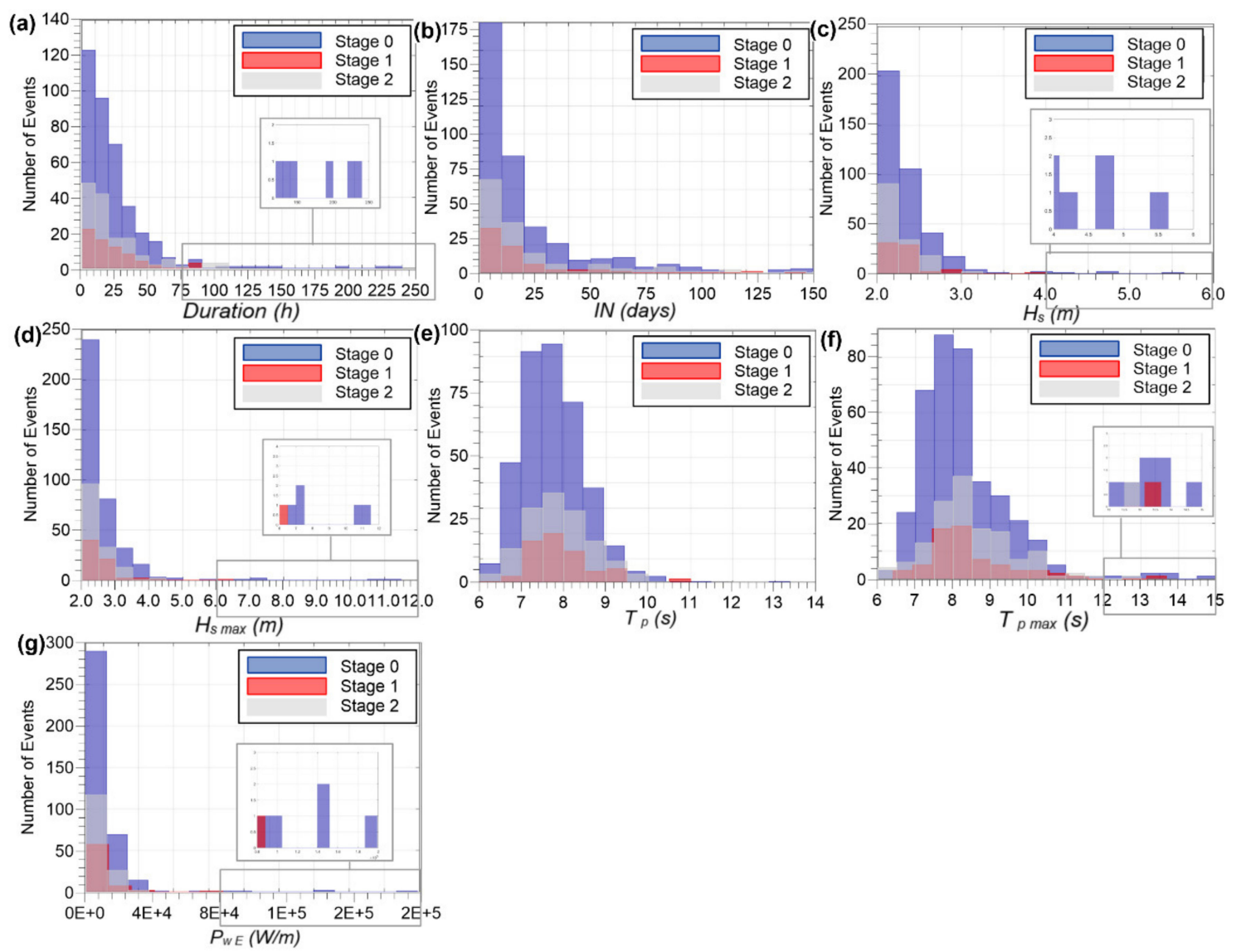

Figure 16. Histograms showing the extreme wave parameters for Stage 0 (blue), Stage 1 (red), Stage 2 (grey); (a) Duration; (b) IN (storm cluster time intervals); (c) $H_{S}$ (significant wave height); (d) $H_{s} \max$ (maximum significant wave height); (e) $T_{p}$ (peak period); (f) $T_{p} \max$ (maximum peak period); (g) $P_{w E}$ (mean wave power by event).

Figure 16 shows quite similar distributions of the variables for all three stages. As the period is much longer, Stage 0 shows a greater number of events in all the histograms and also more events in the tail of the distributions; this is a natural phenomenon. The duration of the individual events shows no significant change between the stages. Of particular interest is the low values of $I N$ found in Stage 2, which show that those storm seasons were more active and, when this time is less than the natural recovery period of the beach, the damage to the beach tends to accumulate. Panels (c), (d), (e) and (f) show that the most intense storms occurred in Stages 0 and 1, whilst in Stage 2 the reduction in the number and intensity of storms is clear.

These findings, analyzed for each stage, are in agreement with the levels of wave power (intensity, persistence) generated by the most intense events. From the information in Figure 16, the levels of erosion reported by [44] can be more clearly understood: in Stage 0 from 1983 to 1990, the eroded area was $218,000 \mathrm{~m}^{2}$; during the $1990 \mathrm{~s}$, the erosion was lower; $19,600 \mathrm{~m}^{2}$, while the eroded surface from April to October 2005 was $265,000 \mathrm{~m}^{2}$. The hydrodynamic characteristics of extreme events and other factors, such as translation speed and trajectory, sea level, wind effects, and sediment properties, contribute to beach erosion. However, it has been reported elsewhere that episodic extreme storms and a series of lesser storms occurring close together could result in greater coastal impact than one single huge storm [45-47]. This means that longer periods of persistently high wave energy can lead to great changes in the beach profile $[48,49]$. Therefore, in this paper, a detailed analysis focusing only on wave power was performed. 
For the study of the wave power, a time series was calculated using the formula for irregular waves (Equation (1)), see Figure 17:

$$
\mathrm{P}_{\mathrm{W}}=\frac{\rho \mathrm{g}^{2}}{64 \pi} \mathrm{H}_{\mathrm{s}}{ }^{2} \mathrm{~T}_{\mathrm{e}}(\mathrm{W} / \mathrm{m}) .
$$

where $H_{s}(\mathrm{~m})$ is the significant wave height and $T_{e}$ is the energy period of the spectra, which can be expressed as a linear function of the mean wave period $T_{01}(\mathrm{~s})$,

$$
\mathrm{T}_{\mathrm{e}}=\frac{\mathrm{m}_{-1}}{\mathrm{~m}_{0}}=\alpha \mathrm{T}_{01}
$$

where $\alpha=1.08$ [43].

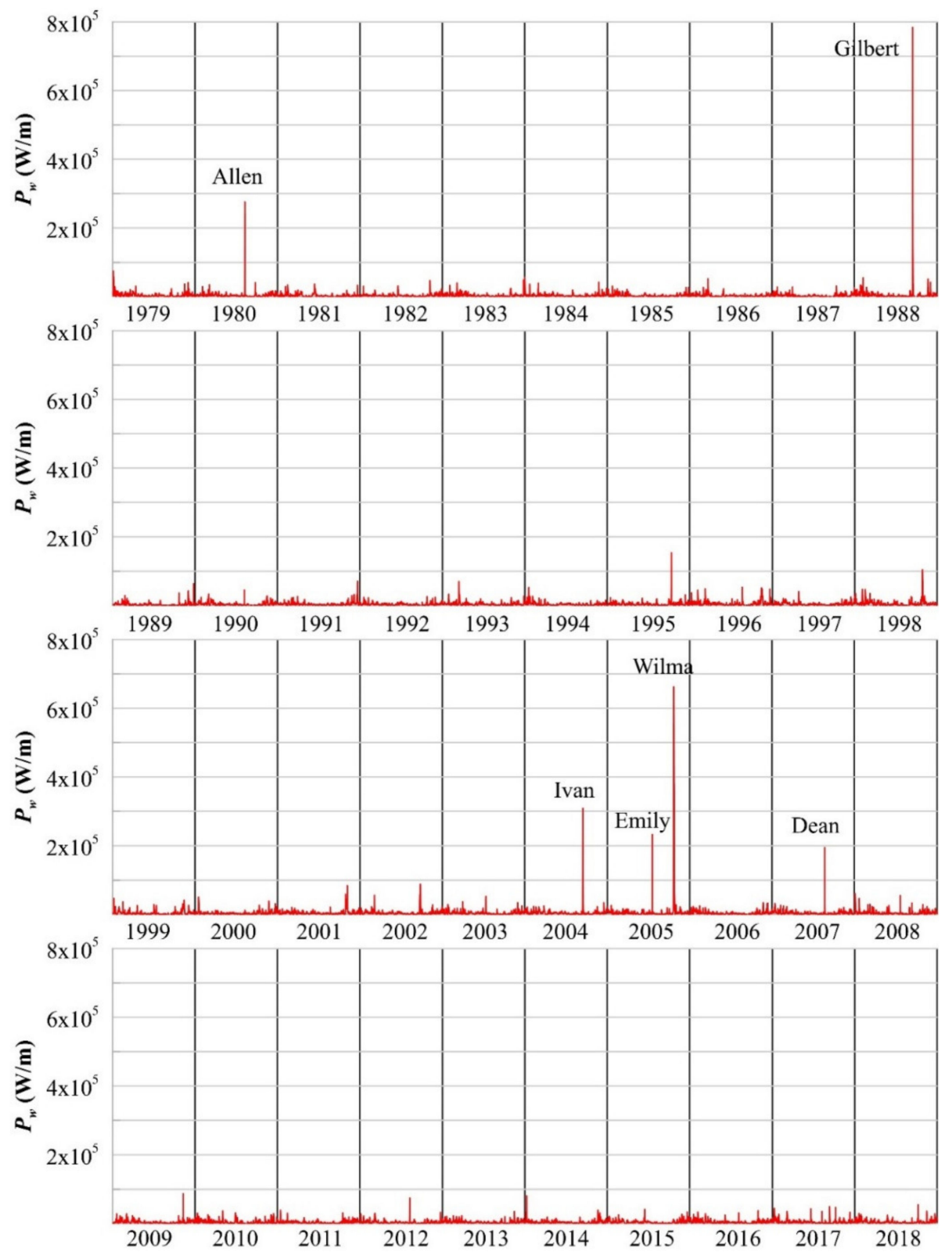

Figure 17. Hourly wave power at $21.0^{\circ} \mathrm{N}$ and $86.5^{\circ} \mathrm{W}$.

From 1979 to 2018 , six events reached or exceeded a maximum wave power of $2 \times 10^{5} \mathrm{~W} / \mathrm{m}$ (see Figure 17); this threshold was selected, being the greatest erosion reported (general knowledge). 
These hurricanes were named Allen (1980), Gilbert (1988), Ivan (2004), Emily (2005), Wilma (2005), and Dean (2007). Their characteristics are presented in Table 1. According to reports, these six hurricanes generated the waves which induced the most severe beach erosion. However, the orders of magnitude of the sand eroded were not directly correlated with the maximum wave power reached in these events. Looking at the dates of the greatest events (Figure 17), and considering their durations (Table 1), together with the largest beach losses reported, erosion seems to be closely related to the intensity and duration of extreme sea states.

Table 1. Wave characteristics of the most extreme storm conditions induced by the hurricanes from 1979 to 2018.

\begin{tabular}{ccccccc}
\hline Event & Allen & Gilbert & Ivan & Emily & Wilma & Dean \\
\hline Date over $10^{4} \mathrm{~W} / \mathrm{m}$ & $07 / 08 / 1980$ & $13 / 02 / 1988$ & $12 / 09 / 2004$ & $17 / 07 / 2005$ & $19 / 10 / 2005$ & $20 / 08 / 2007$ \\
Date $P_{\text {wmax }}$ & $07 / 08 / 1980$ & $14 / 09 / 1988$ & $13 / 09 / 2004$ & $18 / 07 / 2005$ & $21 / 10 / 2005$ & $21 / 08 / 2007$ \\
Duration $(\mathrm{h})$ & 48 & 93 & 90 & 34 & 161 & 44 \\
$\overline{H_{s}}(\mathrm{~m})$ & 3.80 & 4.30 & 3.83 & 3.52 & 5.19 & 3.53 \\
$\bar{H}_{\text {smax }}(\mathrm{m})$ & 7.43 & 11.28 & 7.13 & 6.73 & 10.67 & 6.06 \\
$\overline{T_{p}}(\mathrm{~s})$ & 8.46 & 9.30 & 12.61 & 10.40 & 11.51 & 9.98 \\
$\bar{\theta}$ & 37.00 & 100.56 & 57.59 & 108.33 & 133.21 & 109.12 \\
$P_{\text {wmax }}\left(10^{6} \mathrm{~W} / \mathrm{m}\right)$ & 0.28 & 0.78 & 0.31 & 0.23 & 0.66 & 0.20 \\
$P_{\text {wtotal }}\left(10^{6} \mathrm{~W} / \mathrm{m}\right)$ & 3.85 & 12.30 & 9.51 & 2.48 & 29.42 & 3.23 \\
\hline
\end{tabular}

The arrival direction of the wave power to the shore can limit its erosiveness. For this reason, the dominant direction of the incoming waves from 1979 to 2018 was taken from the same ERA-5 database. The results, separated into Stages 0, 1 and 2, can be seen in Figure 18.
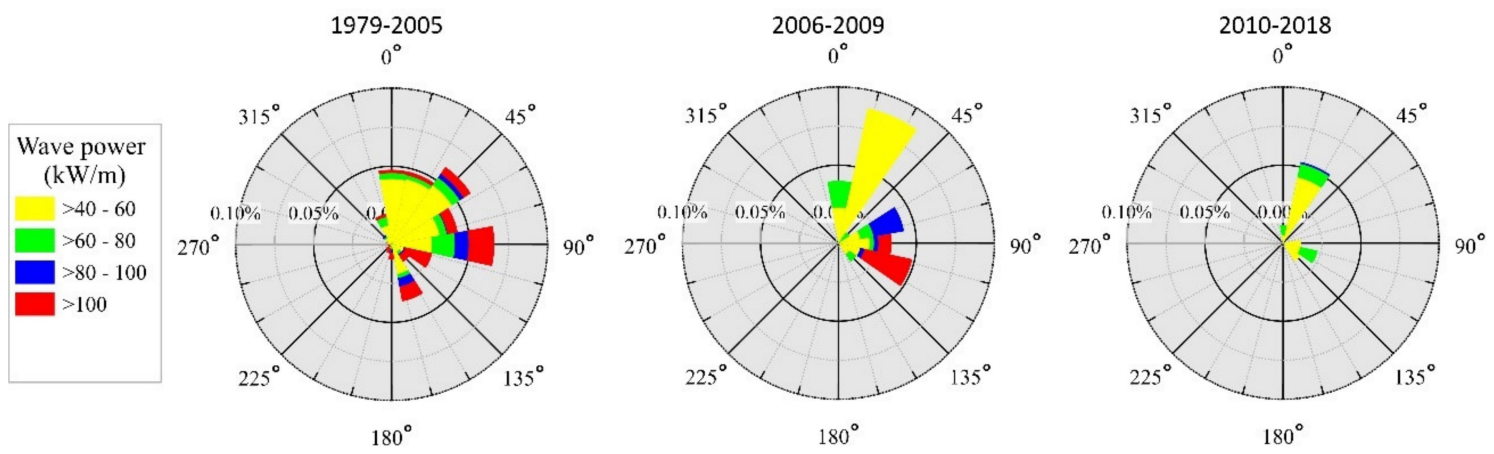

Figure 18. Distribution of the wave power according to incident direction. Stage 0 (1979-2005); Stage 1 (2006-2009); Stage 2 (2010-2018). North direction is $0^{\circ}$.

From Figure 18 it can be inferred that, during Stage 0, the extreme events induced sediment transport to leave the littoral cell in all directions. In Stage 1, most transport was from the south to the north and during Stage 2 no events are found that could produce relevant sediment transport to cause beach loss. The Cancun beach, like any other, has seasonal and interannual variations in erosion-accretion. However, when the wave power exceeds a threshold of around $100 \mathrm{~kW} / \mathrm{m}$, the sand is exported out of the coastal cell and the system is not able to recover naturally

\section{Discussion and Conclusions}

Between 1988 and 2012, six major hurricanes impacted Cancun and information was demanded. As a result, a large number of coastal and oceanographic studies were undertaken, focusing on Cancun, and paying attention to developing human and technical capabilities. Until 2010, the time of the second nourishment, the general perception was that the beach at Cancun had a clear erosion tendency. In this section we will show that this tendency was directly linked to the incidence of extreme hydrodynamic 
conditions and the scarcity of natural sediment sources. These findings could change erroneous perceptions, and present many challenges for future nourishment projects, includes the need for improving long term predictions of wave climate under global warming scenarios.

Previous research $[37,38]$ explained the dynamics of Cancun beach in terms of wave energy fluxes with reasonable accuracy. Therefore, in this paper we opt for a long-term analysis, only evaluating the overall wave power that reaches the beach. With this information, we identified the events which produced the most erosion at Cancun beach. The effects of these climatological events were identified by a cluster analysis which suggested three stages, before the first nourishment (1979-2005), after this (2005-2009), and after the second nourishment (2010-2018). As storms were more frequent in Stages 0 and 1 , the recovery capacity of the beach was debilitated.

The analysis of wave power in the region indicates that for the periods before and after the 2010 sand nourishment, the severity of the hydrodynamic conditions was very different. In the period 1988-2009, the beach was repeatedly affected by intense storms, which induced very high erosion rates. In the period after the second beach nourishment (2010-2018), storm impact was very low. The analysis shows that for the last 8 years, no major hurricanes have impacted the region, and the beach of Cancun has been stable. In this sense, beach stability means that Cancun has maintained a beach width suitable for recreation and for the protection of infrastructure from inundation and damage (i.e., $>40 \mathrm{~m}$ wide) for most of its length, most of the time (see Figure 14). In the absence of hurricanes, all work related to beach monitoring has ceased, despite the importance of Cancun in terms of the tourist industry. Decision makers and investors believe that the beach is stable and that the future of this resort was guaranteed with the second beach nourishment. However, Cancun has taught us that sudden erosion processes occur when we are least prepared.

The considerable amount of sand deposited on the beach ( 8 million cubic meters), along with the low storm impact in the last 13 years, has led the beach away from an erosion tendency. However, it is still too early to assert whether this balance will continue over time, given that the main causes of the erosion are still present.

In the last 50 years of touristic development at Cancun, the exploitation of the dunes, and the use of the beach for recreation, there have been various lessons that should have been learnt:

1. The passage of Hurricane Gilbert in 1988 showed that the resulting erosion put at great risk the touristic infrastructure.

2. Between 1988 and 2004, it was seen that without the presence of very severe waves the beach can slowly and partially recover.

3. During this period, we also learned that the individual "coastal protection" efforts (by hoteliers) in fact increased structural erosion and that such uncoordinated efforts should be avoided. The need for comprehensive coastal management plans and solutions for the entire beach was made evident.

4. The number of nearby sand banks available for borrowing sand is limited; these areas cannot be exploited indefinitely. As this sand is of biogenic origin, the production of these sediments is a very long-term process.

5. Beach scarps are unsuitable for tourism. The design and techniques employed for beach nourishment has to be different, since for long periods the beach profile had a $2 \mathrm{~m}$ scarp.

6. From the morphodynamic behavior of neighboring beaches in the same period, it is evident that the impact of urbanization on dune ecosystems reduces their resilience.

7. The experience gained from the first beach nourishment and subsequent coastal monitoring programs, implemented by government and research bodies, enhanced the design of the second beach nourishment.

8. Much to the contrary of what was previously thought, it has been seen that, in the last 10 years, the beach has not gradually eroded. The erosion events are episodic and the beach may recover again. Nevertheless, it is expected that an extreme event could drive Cancun rapidly to an 
unstable stage, since much of its natural resilience has been lost due to the urbanization of the coastal dunes.

Cancun is a vital asset to the economy of Mexico. In order to have a tourist destination with a healthy sustainable beach, a series of actions are necessary, including the re-establishment of coastal monitoring programs to have more accurate information to correctly diagnose the beach behavior. It is also important to continue comprehensive coastal planning work that allows the coexistence of natural processes and sea-sand-sun tourism.

Author Contributions: Conceptualization, R.M., R.S. and E.M.; methodology, I.M.-T., R.S. and I.O.; software, I.O.; validation, R.S., I.M.-T. and E.M.; formal analysis, E.M. and R.S.; investigation, R.S. and I.O.; resources, R.S. and I.M.-T.; data curation, I.O. and R.S.; writing-original draft preparation, R.M., E.M. and I.M.-T.; writing—review and editing, R.S., E.M. and I.M.-T.; visualization, R.S., E.M. and I.O.; supervision, R.S. and I.M.-T.; project administration, R.S. and I.M.-T.; funding acquisition, R.S. and E.M. All authors have read and agreed to the published version of the manuscript.

Funding: This research received no external funding.

Acknowledgments: The authors wish to thank CONACYT Mexico and CYTED project "Protección de Frentes Urbanos Costeros Frente al Calentamiento Global" under contract P916PTE0234 for partially funding this research.

Conflicts of Interest: The authors declare no conflict of interest.

\section{References}

1. Silva, R.; Martínez, M.L.; Hesp, P.A.; Catalan, P.; Osorio, A.F.; Martell, R.; Fossati, M.; Miot da Silva, G.; Mariño-Tapia, I.; Pereira, P.; et al. Present and future challenges of coastal erosion in Latin America. J. Coast. Res. 2014, 71, 1-16. [CrossRef]

2. Bird, E.C.F. Coastline Changes-A Global Review; John Wiley-Interscience: Chichester, UK, 1985; p. 219.

3. Leatherman, S.P. Beach Response Strategies to Accelerated Sea Level Rise. In Proceedings of the 2nd North American Conference on Preparing for Climate Change, Washington, DC, USA, 6-8 December 1988; pp. 353-358.

4. Cambers, G. Coastlines of the Caribbean. In Proceedings of the 7th Symposium on Coastal and Ocean Management, Long Beach, CA, USA, 8-12 July 1991; ASCE: New York, NY, USA, 1991; p. 187.

5. Escudero, M.; Felix, A.; Silva, R.; Marino-Tapia, I.; Mendoza, E. Beach erosion and loss of protection environmental services in Cancun, Mexico. Ocean Coast. Manag. 2018, 156, 183-197. [CrossRef]

6. Silva, R.; Lithgow, D.; Esteves, L.; Martínez, M.L.; Moreno-Casasola, P.; Martell, R.; Pereira, P.; Mendoza, E.; Campos-Cascaredo, A.; Winckler-Grez, P.; et al. Coastal Risk Mitigation by Green Infrastructure in Latin America. Proc. Inst. Civ. Eng.-Mar. Eng. 2017, 170, 39-54. [CrossRef]

7. Silva, R.; Chávez, V.; Bouma, T.J.; van Tussenbroek, B.I.; Arkema, K.K.; Martínez, M.L.; Oumeraci, H.; Heymans, J.J.; Osorio, A.F.; Mendoza, E. The incorporation of biophysical and social components in coastal management. Estuar. Coast 2019, 42, 1695-1708. [CrossRef]

8. Dean, R.G.; Dalrymple, R.A. Coastal Processes with Engineering Applications; Cambridge University Press: Cambridge UK, 1988; p. 489.

9. Stive, M.J.F.; De Schipper, M.A.; Luijendijk, A.P.; Ranasinghe, R.W.M.R.J.B.; Van Thiel De Vries, J.S.M.; Aarninkhof, S.; Marx, S. The Sand Engine: A solution for vulnerable deltas in the 21st century? In Proceedings of the Coastal Dynamics 2013: 7th International Conference on Coastal Dynamics, Arcachon, France, 24-28 June 2013.

10. Escudero, M.; Mendoza, E.; Silva, R. Micro sand engine beach stabilization strategy at Puerto Morelos, México. J. Mar. Sci. Eng. 2020, 8, 247. [CrossRef]

11. Dean, R.G. Additional Sediment Input to the Nearshore Region. Shore Beach 1987, 55, 76-81.

12. CUR. Manual on Artificial Beach Nourishment; Codes and Specifications, Repot 130; Centre for Civil Engineering Research: Gouda, The Netherlands, 1987; p. 195.

13. Davison, A.T.; Nicholls, R.J.; Laetherman, S.P. Beach Nourishment as a Coastal Management Tool: An Annotated Bibliography on Developments Associated with the Artificial Nourishment of Beaches. J. Coast. Res. 1992, 8, 984-1022. 
14. Walker, H.J.; Finkl, C.W. Beach nourishment: Case studies. In Engineered Coasts; Kluwer Academic Publishers: Dordrecht, The Netherlands, 2002; pp. 23-60.

15. Bruun, P. Coast Erosion and the Development of Beach Profiles; Tech. Memo No. 44; US Beach Erosion Board: Washington, DC, USA, 1954; p. 79.

16. Bagnold, R.A. Mechanics of Marine Sedimentation; Sea, M.N., Ed.; Interscience: New York, NY, USA, 1963; pp. 507-528.

17. Komar, P.D. Beach Processes and Sedimentation; Prentice Hall: Upper Saddle River, NJ, USA, 1973; p. 544.

18. Dean, R.G. Heuristic Models of Sand Transport in the Surf Zone. In Proceedings of the Conference on Engineering Dynamics in the Surf Zone, Sydney, Australia, 1973; pp. 208-214.

19. James, W.R. Beach Fill Stability and Borrow Material Texture. In Proceedings of the 14th ICCE, Copenhagen, Denmark, 24-28 June 1974; ASCE: Reston, VA, USA, 1974; pp. 1334-1349.

20. Van Rijn, L.C. Principles of Coastal Morphology; Aqua Publications: Amsterdam, The Netherlands, 1988.

21. Herbirch, J.B. Handbook of Coastal Engineering; McGraw-Hill: New York, NY, USA, 2000.

22. Woodroffe, C.D. Coast: Form, Process and Evolution; Cambridge University Press: Cambridge, UK, 2002.

23. Dean, R.G. Beach Nourishment: Theory and Practice; World Scientific Publishing Co. Pte. Ltd.: Singapore, 2002; p. 420.

24. TAW. Guidelines for the Evaluation of Safety of Dunes as Coastal Defense (English Translation of the Official Dutch Guidelines); CUR Publishing Foundation: Gouda, The Netherlands, 1986; p. 26.

25. Van de Graaff, J. Probabilistic design of dunes: An example from The Netherlands. Coast. Eng. 1986, 9, 479-500. [CrossRef]

26. Van Slobbe, E.; de Vriend, H.J.; Aarninkhof, S.; Lulofs, K.; de Vries, M.; Dircke, P. Building with Nature: In search of resilient storm surge protection strategies. Nat. Hazards 2013, 66, 1461-1480. [CrossRef]

27. Martínez, M.L.; Taramelli, A.; Silva, R. Resistance and resilience: Facing the multidimensional challenges in coastal areas. J. Coast. Res. 2017, 77, 1-6. [CrossRef]

28. National Research Council. Beach Nourishment and Protection; National Academy Press: Washington, DC, USA, 1995.

29. Martell, R.; Mariño, I.; Mendoza, E.; Silva, R. Variaciones morfológicas a largo plazo del perfil de playa en Cancún, México. In Proceedings of the XXI Congreso Nacional De Hidráulica, Jalisco, México, 25 November 2010; p. 8.

30. Mendoza, E.; Silva, R.; Enriquez-Ortiz, C.; Mariño-Tapia, I.; Felix, A. Analysis of the Hazards and Vulnerability of the Cancun Beach System, in Extreme Events: Observations, Modeling, and Economics; Chavez, M., Ghil, M., Urrutia-Fucugauchi, J., Eds.; John Wiley \& Sons, Inc.: Hoboken, NJ, USA, 2015; pp. 125-136.

31. Villatoro, M.M.; Escudero, M.C.; Mendoza, E.; Silva, R. Chapter 7.7. Balancing flood and erosion risk with landscape sustainability: Cancun, Mexico. In Coastal Risk Management in a Changing Climate; Zanuttigh, B., Nicholls, R., Vanderlinden, J.-P., Thompson, R., Burcharth, H., Eds.; Elsevier: Amsterdam, The Netherlands, 2014; pp. 506-534.

32. Martell, R.; Mariño, I.; Mendoza, E.G.; Silva, R. Variaciones morfológicas, inducidas por condiciones hidrodinámicas extremas, en la playa de Cancún, México. XXV Congreso Latinoamericano de Hidráulica, San José, Costa Rica, 12 September 2012; p. 10.

33. CFE. Restauración, recuperación, sostenimiento y mantenimiento de la zona federal marítimo terrestre de Cancún, Playa del Carmen y Cozumel; Manifestación de impacto Ambiental, presentada a SEMARNAT. $2009 ; 120$.

34. Silva, R.; Mariño, I.; Enriquez, C.; Mendoza, E.; Escalante, E.; Ruiz, F. Monitoring Shoreline Changes at Cancun Beach, Mexico: Effects of Hurricane Wilma; Word Scientific Publishing, ICCE Coastal Engineering: San Diego, CA, USA, 2006; pp. 3491-3503.

35. Félix, A. Análisis de la dinámica geomorfológica de la zona hotelera de Cancún como contribución al desarrollo de un Plan de Manejo Costero. MSc Thesis, Universidad Autónoma de Campeche, Campeche, México, 2007.

36. Martell, R.; Mariño, I.; Mendoza, E.; Silva, R. Análisis del oleaje swell y sea generado por los huracanes Wilma (2005) y Dean (2007). In Proceedings of the XXII Congreso Nacional de Hidráulica, Guerrero, México, 12 September 2012; AMH: Adelaide, Australia, 2012; p. 8. 
37. González-Leija, M.; Mariño-Tapia, I.; Silva, R.; Enriquez, C.; Mendoza, E.; Escalante-Mancera, E.; Ruíz-Rentería, F.; Uc-Sánchez, E. Morphodynamic Evolution and Sediment Transport Processes of Cancun Beach. J. Coast. Res. 2013, 29, 1146-1157. [CrossRef]

38. Ruiz de Alegria-Arzaburu, A.; Mariño-Tapia, I.; Silva, R.; Pedrozo-Acuña, A. Post-nourishment beach scarp morphodynamics. J. Coast. Res. 2013, 65, 576-581. [CrossRef]

39. Webcams de México. Available online: wabcamsdemexico.com (accessed on 15 February 2020).

40. Copernicus Climate Change Service (C3S). ERA5: Fifth Generation of ECMWF Atmospheric Reanalyses of the Global Climate; Copernicus Climate Change Service Climate Data Store (CDS): Barcelona, Spain, 2018.

41. Bromirski, P.D.; Cayan, D.R.; Helly, J.; Wittmann, P. Wave Power Variability and Trends across the North Pacific. J. Geophys. Res. Oceans 2013, 118, 6329-6348. [CrossRef]

42. Harley, M. Coastal Storm Definition. In Coastal Storms: Processes and Impacts; Ciavola, P., Coco, G., Eds.; John Wiley \& Sons: Hoboken, NJ, USA, 2017; pp. 1-19.

43. Dissanayake, P.; Brown, J.; Wisse, P.; Karunarathna, H. Effects of storm clustering on beach/dune evolution. Mar. Geol. 2015, 370, 63-75. [CrossRef]

44. Silva, R.; Ruiz-Martinez, G.; Mariño-Tapia, I.; Posada-Vanegas, G.; Mendoza, E.; Escalante-Mancera, E. Manmade vulnerability of the Cancun Beach system: The case of hurricane Wilma. Clean (Weinh) 2012, 40, 911-919.

45. Coco, G.; Senechal, N.; Rejas, A.; Brian, K.R.; Capo, S.; Parisot, J.P.; Brown, J.A.; MacMahan, J.H.M. Beach response to sequence of extreme storms. Geomorphology 2014, 204, 493-501. [CrossRef]

46. Dolan, R.; Davies, R.E. Coastal storm hazards. J. Coast. Res. 1994, 12, 103-114.

47. Karunarathna, H.; Pender, D.; Ranasinghe, R.; Short, A.D.; Reeve, D.E. The effects of storm clustering on beach profile variability. Mar. Geol. 2014, 348, 103-112. [CrossRef]

48. Silva, R.; Martínez, M.; Odériz, I.; Mendoza, E.; Feagin, R. Response of vegetated dune-beach systems to storm conditions. Coast. Eng. 2016, 109, 53-62. [CrossRef]

49. De Vries, J.v.T.; Van Gent, M.; Walstra, D.; Reniers, A. Analysis of dune erosion processes in large-scale flume experiments. Coast. Eng. 2008, 55, 1028-1040. [CrossRef]

(C) 2020 by the authors. Licensee MDPI, Basel, Switzerland. This article is an open access article distributed under the terms and conditions of the Creative Commons Attribution (CC BY) license (http://creativecommons.org/licenses/by/4.0/). 